\title{
RESEARCH NOTE \\ Identification and characterization of an original grapevine cultivar (Vitis vinifera) found in Chile
}

\author{
Alvaro S. Gonzalez ${ }^{1}$, Franco Massera ${ }^{1}$, Daniel Moscoso ${ }^{1}$, Patricio \\ Hinrichsen $^{2}$, Gloria Montenegro ${ }^{1}$, Valerie Laucou ${ }^{3}$, Thierry Lacombe ${ }^{3}$, Jean- \\ Michel Boursiquot ${ }^{3}$, and Philippo Pszczólkowski ${ }^{1}$ \\ ${ }^{1}$ Facultad de Agronomía e Ingeniería Forestal, Pontificia Universidad Católica de Chile. Vicuña Mackenna \\ 4860. Macul, Santiago, Chile. \\ ${ }^{2}$ Centro Regional de Investigación La Platina, Instituto de Investigaciones Agropecuarias, INIA. Santa Rosa \\ 11610, La Pintana, Santiago, Chile. \\ ${ }^{3}$ INRA Montpelier SupAgro, UMR 1334 AGAP, Equipe DAVEM, 2 place Pierre Viala, 34060 Montpellier \\ cedex 1, France.
}

\begin{abstract}
A.S. Gonzalez, F. Massera, D. Moscoso, P. Hinrichsen, G. Montenegro, V. Laucou, T. Lacombe, J.-M. Boursiquot, and Ph. Pszczólkowski. 2016. Identification and characterization of an original grapevine cultivar (Vitis vinifera) found in Chile. Cien. Inv. Agr. 43(2):337-345. Currently, many monovarietal vineyards present a minority of mixed cultivars. Some of these cultivars are unknown and could represent an opportunity to discover new and potentially useful genotypes both for research and production purposes. In a 'Carmenère' vineyard planted in 1994 in Palmilla (Colchagua Valley, Chile), a minority presence of other cultivars was found. The present work covers for the first time the identification and characterization of one of these cultivars, which presented a very poor fruit set. Through classic ampelography, it was not possible to associate the studied cultivar with any known cultivar in Chile. However, through a simple sequence repeats (SSR) comparison against the database of the INRA Germplasm Repository "Domaine de Vassal" in France, the cultivar was identified as a triploid accession named 'Folle Blanche Faux' (Vitis vinifera L.) that was previously found in Chile during the season of 1950-1951. This cultivar presents earlier bud breaking than 'Carmenère', has morphologically complete flowers, and shows a physiological disorder around the fruit set, leading to partial or complete bunch necrosis under the environmental conditions of Palmilla. This cultivar contributes to the genotypic richness present in Chile and might be an interesting tool for physiological and molecular studies. It also could become productive under other environmental conditions (i.e., environmental conditions that favor a good fruit set) or by the application of adequate vineyard practices, such as cane girdling at bloom time.
\end{abstract}

Key words: Ampelography, Chile, coulure, molecular markers, poor fruit set, SSR, triploid.

\section{Introduction}

The grapevine is one of the oldest perennial crops in the world. Today, it is cultivated to produce wine,

Received August 24, 2015. Accepted July 6, 2016.

Corresponding author: philippo@uc.cl juice, table grapes and raisins, making it one of the most important crops around the world. Chilean viticulture dates back to the early 16th-century Spanish colonization (Milla-Tapia et al., 2007) and is based on Vitis vinifera L. cultivars that were brought from Spain during the 16th century and 
France during the 19th century. The number of $V$. vinifera cultivars referenced around the world was estimated to be approximately 10,000 (Alleweldt and Dettweiler, 1994), but there is still a great number of unreferenced cultivars, whose genotype and characteristics are unknown or barely described.

During the last Chilean wine industry crisis, vineyard plantations dropped from 109,500 hectares in 1979 (Hernández and Pszczólkowski, 1986) to 53,093 hectares in 1994. Plantations in Chile resumed in 1994 and increased in 2014 to an area of 137,592 hectares (SAG, 2015). This last plantation cycle was broadly performed under an old technological paradigm, i.e., the mass selection and obtainment of plant material from renowned vineyards, without a prior sanitary and varietal selection process. These vineyards frequently present a mixture of cultivars and some pathological problems, such as grapevine trunk diseases, viral diseases, and nematodes (Díaz et al., 2013). The mixture of cultivars represents a problem for exporters of varietal labeled wines due to international trade regulations. Therefore, most current growers make efforts to plant genetic and sanitary certified vegetal material and correctly identify the cultivars in their old vineyards. Nevertheless, there are still unidentified cultivars in vineyards around the world and Chile. They represent an interesting germplasm reservoir, an opportunity with potential applications in grapevine research and the wine industry.

The objectives of this investigation were as follows: (1) to identify an unknown cultivar that was found in a minority proportion mixed in a vineyard using classic ampelography and molecular genetic markers; (2) to describe its characteristics and phenology; and (3) to induce fruit setting by cane girdling, a viticultural practice that could be used for this purpose (Gil and Pszczólkowski, 2015).

\section{Materials and methods}

Plant material. An unknown cultivar was found inside a commercial vineyard primarily planted with cv. 'Carmenère', located in Palmilla, Colchagua Valley, Chile $\left(34.55^{\circ} \mathrm{S} 71.40^{\circ} \mathrm{W}\right)$, under a sub-humid Mediterranean climate (Di Castri and Hajek, 1976). Of a total of 112 specimens $(1.13 \%$ of the complete vineyard) identified as the unknown cultivar and marked in a previous season, 12 plants were selected for this study. The study was performed during the 2012/2013 season. Grapevines were trained as a traditional vertical trellis with cane pruning (two canes per plant with eight to twelve buds per cane). The plants were 18 years old and own-rooted, and the planting density was 3,200 vines per hectare.

Classical ampelographic description. The unknown cultivar characteristics were defined and measured according to the OIV descriptor list for grapevine cultivars and Vitis species (OIV, 2006). Ampelographic observations were made during a single vegetative season for the 12 selected specimens. The shoots were examined on September 27 (BBCH or Einhorn-Lorenz system, E-L 12) when they were approximately 10 to 20 $\mathrm{cm}$ in height, and the first five distal leaves of the young shoots were evaluated. Mature leaf descriptions were obtained at the beginning of flowering (E-L 19) and were performed on leaves distal to the inflorescences, in the middle section of the shoot. The berry characteristics were obtained from the few berries left after necrosis took place.

Microsatellite analysis. Samples for molecular marker analyses were collected before flowering (October 11; E-L 15). One shoot was taken from each selected plant. DNA was extracted from the young leaves and stored at $-80{ }^{\circ} \mathrm{C}$, as described elsewhere (Narváez et al., 2001). The following fifteen microsatellite loci were used to genotype all accessions: VVMD5, VVMD7, VVMD21, VVMD24, VVMD25, VVMD27, VVMD28, VVMD32 (Bowers et al., 1996), VVS2 (Thomas and Scott, 1993), VrZAG29, VrZAG62, VrZAG67, VrZAG79, VrZAG83 and VrZAG112 (Sefc et al., 2000). Polymerase chain reaction (PCR) was 
carried out as has been described (Mejía et al., 2007) in a final volume of $10 \mu \mathrm{L}$ containing 20 ng total DNA, $10 \mathrm{mM}$ tris $\mathrm{HCl}, 50 \mathrm{mM} \mathrm{KCl}(\mathrm{pH}$ 8.3), $2 \mathrm{mM} \mathrm{MgCl} 2,200 \mathrm{mM}$ of each dNTP, $5 \%$ DMSO, $0.2 \mu \mathrm{M}$ each forward and reverse primers, and $0.4 \mathrm{U}$ Taq DNA polymerase. Amplification was carried out using a touchdown amplification program, as described by Milla-Tapia et al. (2007). After separating the amplicons in 6\% denaturant polyacrylamide-TBE gels, they were revealed by silver staining, as previously described (Mejía et al., 2007). The simple sequence repeats (SSR) allelic patterns were compared with the available databases at INIA (Santiago, Chile) and the INRA Grape Germplasm Repository at Domaine de Vassal (Marseillan, France; http:// wwwl.montpellier.inra.fr/vassal/).

Histological study. Inflorescence samples were extracted on November 6 and 16, 2012, fixed in formalin/acetic acid/alcohol (FAA) and impregnated in paraffin. Several flower sections were studied under the microscope. The methodology comprises several steps as follows: dehydration with butyric and ethylic alcohols, elution of paraffin in xylol, safranin-fast green staining and finally embedding in Entellán ${ }^{\circledR}$ rapid mounting medium for microscopy (Merck KGaA, Darmstadt, Germany), as described by Calderón-Baltierra et al. (2004). A Leitz 1212 rotation microtome (Leica Microsystems GmbH, Wetzlar, Germany) was used to produce transversal, longitudinal, radial and tangential sections of 10 to 25 microns. The microscopic analysis was performed with an Optiphot FX-35/A microscope (Nikon Corp., Tokyo, Japan).

Photographic tracking. Normal shoots were selected and marked from the selected plants. A photographic tracking of each shoot's first inflorescence/bunch was performed on 12 dates between the moment when the inflorescences were clearly visible (E-L 12; September 27) and the beginning of the bunch closure (E-L 32; December 14) using a Lumix DMC-ZS7 camera (Panasonic Corp., Osaka, Japan).
Cane girdling experiment. The twelve selected plants of the unknown cultivar were selected; six were left without cane girdling as a control, and six were girdled. In each plant, two normal shoots (10 to $20 \mathrm{~cm}$ long) were labeled, and the basal inflorescence of each of them was selected for photographic tracking to study the bloom characteristics and the effect of cane girdling on the fruit set.

Winemaking. Small-scale winemaking procedures were performed for the grapes of the unknown cultivar (obtained after the cane girdling treatment), without replicates. The wine was made through the traditional red and rosé wine fermentation protocols. The grapes were picked on a single date, April 27, 2013 (corresponding to $25.7^{\circ}$ Brix). Two $25-\mathrm{kg}$ grape batches were harvested from the previously identified plants. Fermentation was carried out in 25-L containers in a controlled temperature room $\left(15^{\circ} \mathrm{C}\right.$ for rosé and $25^{\circ} \mathrm{C}$ for red fermentation) with Rhone 2056 selected yeast $\left(20 \mathrm{~g} \mathrm{hL}^{-1}\right)$. Complete spontaneous malolactic fermentation was performed for the red wine. An adjustment to $35 \mathrm{mg} \mathrm{L}^{-1}$ free sulfur dioxide was made in all the wines prior to bottling.

Must and wine analyses. The total soluble solids was determined by direct reading with a digital refractometer (Pocket PAL-1, Atago, Japan), the $\mathrm{pH}$ using a $\mathrm{pH}$ meter (Orion 5-Star, Thermo Scientific, Singapore) and the titratable acidity using a $\mathrm{pH}$ meter and $0.1 \mathrm{~N} \mathrm{NaOH}$. The alcoholic strength was determined by the use of an "Alcodest" distillation unit (JP SELECTA SA, Barcelona, Spain). The phenolic composition and color of the wines were determined using a UV/Vis spectrophotometer model Spectronic Genesys 2 (Milton Roy, Rochester, NY). All the analyses were performed according to the methods described by Iland et al. (2004).

Statistical analysis. The data were analyzed and compared using Excel (Microsoft, Redmond, Washington, USA). 


\section{Results and discussion}

Identification by molecular markers. The SSR allelic patterns of the unknown cultivar and the other cultivars analyzed for comparison (Cabernet Franc, Cabernet-Sauvignon, Carmenère, Merlot, Côt, Pinot Noir, Syrah, País, Perlette, Centennial and Black Seedless) are shown in Table 1. The SSR pattern of the unknown cultivar was different from all the cultivars used for comparison. Four of these cultivars ('Merlot', 'Carmenère', 'Cabernet Franc' and 'Cabernet-Sauvignon') shared at least one allele with every SSR marker studied, suggesting a close parentage. The fractions of shared alleles with the unknown cultivar ranged from 0.58 to 0.67 as shown in Table 1, including three table grape cultivars that ranged from 0.33 to 0.36 . The SSR pattern of the unknown cultivar was different from the over 200 genotypes registered at the INIA database (Chile), but it fully matched an accession found in the INRA - Domaine de Vassal database as follows: a triploid accession coming from Chile named 'Folle Blanche Faux' (European Vitis Database accession number: FRA139-0Mtp384). The accession was introduced in the Vassal Collection in the winter season of 1951-1952 from Chile, as wrong (i.e., "faux" in French) 'Folle Blanche', a known old cultivar from the west side of France that has white grapes and is traditionally used in the Cognac and Armagnac regions (Boidron et al., 1995). The similarities between the morphologies and SSR allelic patterns of 'Folle Blanche Faux' and the other wine grape genotypes (Table 1) is presumably related to the origin of this cultivar in the south-western region of France.

As a future task, the triploid character of this cultivar needs confirmation. This cultivar could also be a cytochimera, which is a type of genetic mosaic or a mixture of genetically different tissues having various ploidy levels (Pelsy, 2010), as was first observed by Einset and Pratt (1954) in the cell layers of grapevine shoot apical meristems. As a confirmation of the triploid nature of this cultivar, the analysis of different grapevine organs will be needed.
Ampelography and phenology. The major ampelographic characteristics are shown in Figure 1 and Table 2. The shoot tip (Figure 1B) has a piping distribution, a medium intensity of anthocyanin coloration on the prostrate hairs and a medium density of erect hairs. The shoot growth habit is semi-erect (Figure 1A). The mature leaf (Figure 1D) has five lobes and a convex teeth shape. The flower (Figure 1C) has fully developed stamens and gynoecium. The flowers were found to be morphologically complete (Figure 1C), but the inflorescences/bunches showed a severe physiological disorder at the moment of fruit set, beginning with stigma necrosis and followed by complete bunch necrosis under the existing local plant and environmental conditions. All these characteristics (Table 2) together do not agree with those of any of the cultivars present in the Chilean legislation or previously known by the authors (Gil and Pszczólkowski, 2015). On the other hand, the unknown cultivar showed an earlier development of the phenological stages when compared with cv. 'Carmenère' from budburst until harvest-ripe berries (Table 3).
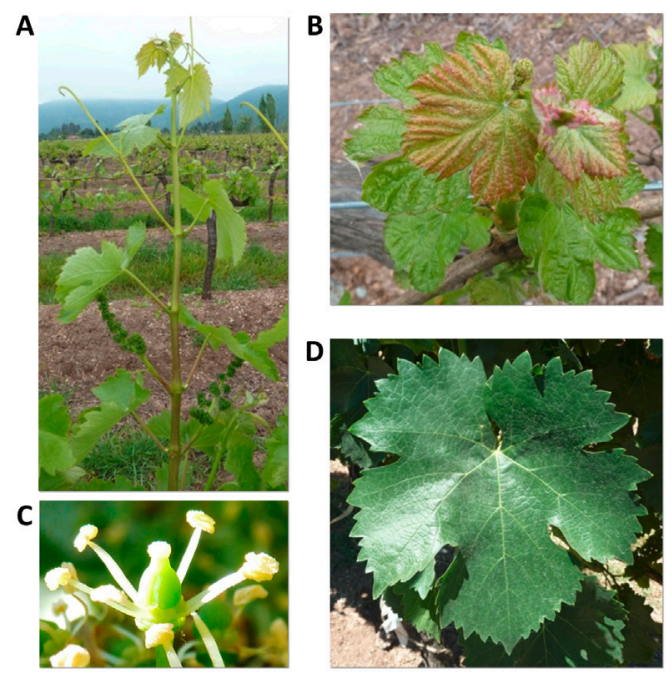

Figure 1. Ampelographic characteristics of the unknown cultivar: shoot (A), young leaves (B), flower (C) and mature leaf (D).

Inflorescence and flower necrosis. The unknown cultivar presents severe flower coulure, leading 


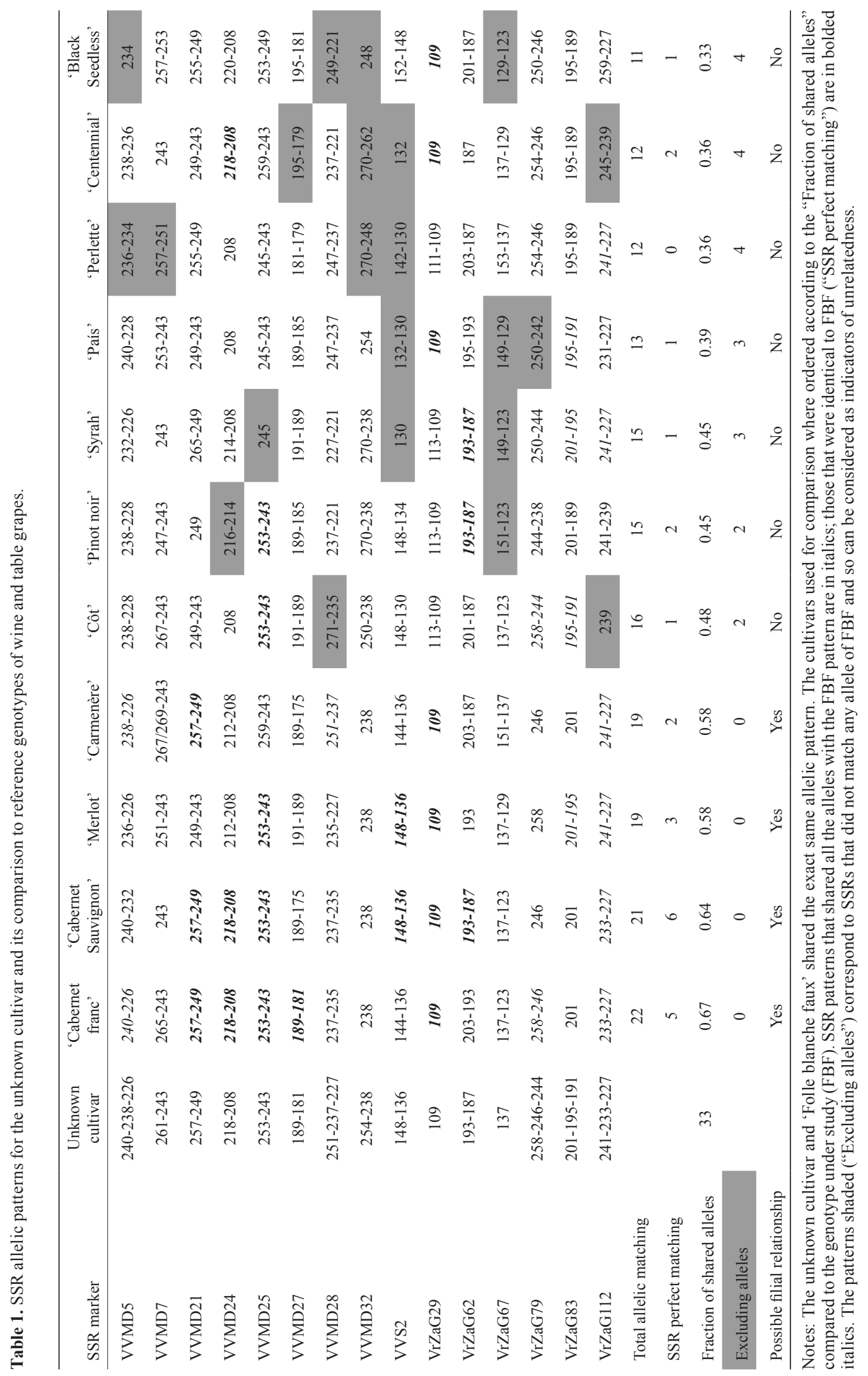


Table 2. Primary OIV descriptor priority list (OIV, 2006), for a quick characterization of the unknown cultivar.

\begin{tabular}{|c|c|c|c|}
\hline OIV Code & Organ & Characteristic & Notes \\
\hline 1 & \multirow{2}{*}{ Young shoot } & Opening of the shoot tip & Fully open \\
\hline 4 & & Density of prostrate hairs on the shoot tip & High \\
\hline 16 & Shoot & Number of consecutive tendrils & Two or fewer \\
\hline 51 & \multirow[t]{3}{*}{ Young leaf } & Color of upper side of blade (4th leaf) & Bronze \\
\hline 67 & & Shape of blade & Circular \\
\hline 68 & & Number of lobes & Five \\
\hline 70 & \multirow{5}{*}{ Mature leaf } & $\begin{array}{c}\text { Area of anthocyanin coloration of main veins on } \\
\text { upper side of blade }\end{array}$ & Absent \\
\hline 76 & & Shape of teeth & Both sides convex \\
\hline 79 & & Degree of opening / overlapping of petiole sinus & Overlapped \\
\hline $81-2$ & & Petiole sinus base limited by vein & Not limited \\
\hline 84 & & $\begin{array}{c}\text { Density of prostrate hairs between main veins on } \\
\text { lower side of blade }\end{array}$ & Low \\
\hline 87 & & $\begin{array}{l}\text { Density of erect hairs on main veins on lower side } \\
\text { of blade }\end{array}$ & None or very low \\
\hline 223 & \multirow{2}{*}{ Berry } & Shape & Globose \\
\hline 225 & & Color of skin & Red \\
\hline
\end{tabular}

Table 3. Dates of occurrence of phenological grapevine growth stages for the unknown cultivar and cv. 'Carmenère', according to the adapted BBCH (E-L) system.

\begin{tabular}{|c|c|c|c|}
\hline E-L No & Phenological stage & Unknown cultivar & 'Carmenère' \\
\hline 2 & Budswell & & 01-Sep \\
\hline 3 & Woolly bud-brown wool visible & 01-Sep & \\
\hline 7 & First leaf separated from shoot tip & & 27-Sep \\
\hline 12 & $\begin{array}{l}5 \text { leaves separated; shoots approximately } 10 \mathrm{~cm} \text { long; } \\
\text { inflorescence clear }\end{array}$ & 27-Sep & $11-$ Oct \\
\hline 15 & $\begin{array}{l}8 \text { leaves separated, shoot elongating rapidly; single flowers } \\
\text { in compact groups }\end{array}$ & $11-$ Oct & 27-Oct \\
\hline 17 & $\begin{array}{c}12 \text { leaves separated; inflorescence well developed, single } \\
\text { flowers separated }\end{array}$ & 27-Oct & 03-Nov \\
\hline 19 & $\begin{array}{c}\text { Approximately } 16 \text { leaves separated; beginning of flowering } \\
\text { (first flower caps loosening) }\end{array}$ & 03-Nov & 06-Nov \\
\hline 21 & $30 \%$ caps off & 06-Nov & 09-Nov \\
\hline 23 & $17-20$ leaves separated; $50 \%$ caps off $(=$ full-bloom $)$ & 09-Nov & 13-Nov \\
\hline 25 & $80 \%$ caps off & $13-\mathrm{Nov}$ & $16-\mathrm{Nov}$ \\
\hline 26 & Cap-fall complete & 16-Nov & 19-Nov \\
\hline 27 & $\begin{array}{l}\text { Setting; young berries enlarging ( }>2 \mathrm{~mm} \text { diam.), bunch at } \\
\text { right angles to stem }\end{array}$ & 19-Nov & 22-Nov \\
\hline 29 & $\begin{array}{c}\text { Berries peppercorn size ( } 4 \mathrm{~mm} \text { diam.); bunches tending } \\
\text { downwards }\end{array}$ & 22-Nov & 29-Nov \\
\hline 31 & Berries pea-size ( $7 \mathrm{~mm}$ diam.) & 29-Nov & \\
\hline 32 & $\begin{array}{l}\text { Beginning of bunch closure, berries touching (if bunches } \\
\text { are tight) }\end{array}$ & 14-Dec & \\
\hline 38 & Berries harvest-ripe & 13-Mar & 05-Apr \\
\hline
\end{tabular}


to an extremely poor fruit set (0-10\%). In agreement with our observations, the grape breeder and ampelographer Paul Truel, in unpublished data from the INRA Domaine de Vassal archives (personal communication, 1959), described this cultivar as having morphologically hermaphrodite flowers but being non-fertile because of a very important coulure every year. Exceptionally, a few flowers were pollinated and fertilized, giving rise to large seeded berries. In our present work, the study of the few berries left after fruit set shows that they are able to grow and ripen. Between September 27 and November 6, a normal development of inflorescences was observed. The unknown cultivar showed a physiological disorder in its inflorescences, initially characterized by the necrosis of the stigma tissue on November 9 (E-L 23) followed by the full necrosis of the inflorescence (Figure $2 \mathrm{~A}$ and $\mathrm{C}$ ), which could be associated with the triploid nature (Park et al., 2002; Staudt, 1995) and/or a high sensitivity to early bunch stem necrosis (EBSN) (Jackson, 1991). The flower tissues, particularly the ovary wall, showed high accumulations of phenolic compounds (Figure 3) at the end of the cap-fall stage (E-L 26). After fruit set, it is possible to observe complete necrosis in the inflorescences and some inflorescences that could set one seeded berry (Figure $2 \mathrm{~B}$ and D). Only one inflorescence (out of twelve) did not show complete necrosis, presumably because of the presence of a single seeded berry in the cluster.

Effects of cane girdling. Using cane girdling, this cultivar did not experience bunch necrosis (which normally leads to no production at all), setting berries that fully developed and ripened in a cluster with one large shoulder and producing grapes for the first time, as shown in Figure 4. The developed berries on the treated canes were mostly seedless. In the future, a thorough knowledge of the inflorescence and flower development is needed to understand the poor fruit setting behavior of this cultivar and the nature of bunch necrosis. Must from the harvested berries presented low $\mathrm{pH}$ and high acidity. Rosé and red wines presented normal to high alcohol content and normal color (Table 4).
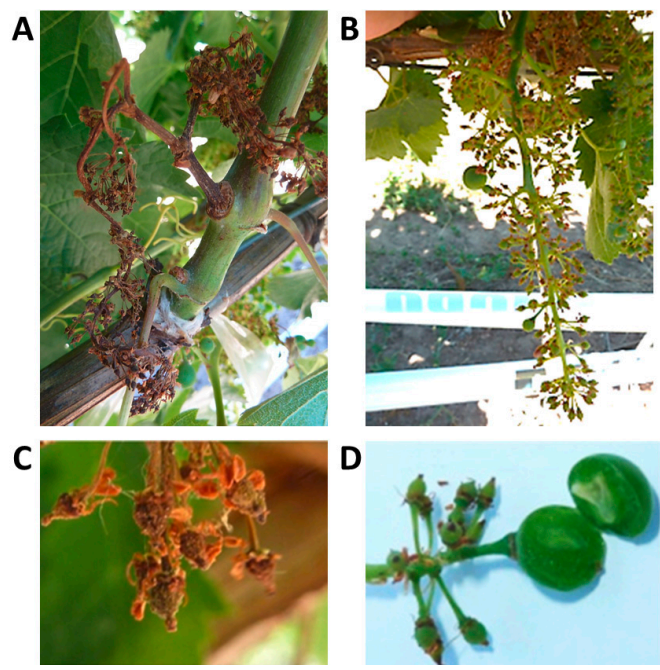

Figure 2. Necrotic inflorescence (A), non-fertilized flowers after bloom on December 14 (C), unfertilized flowers, seeded berries and very small seedless berries on November 29 (B, D).
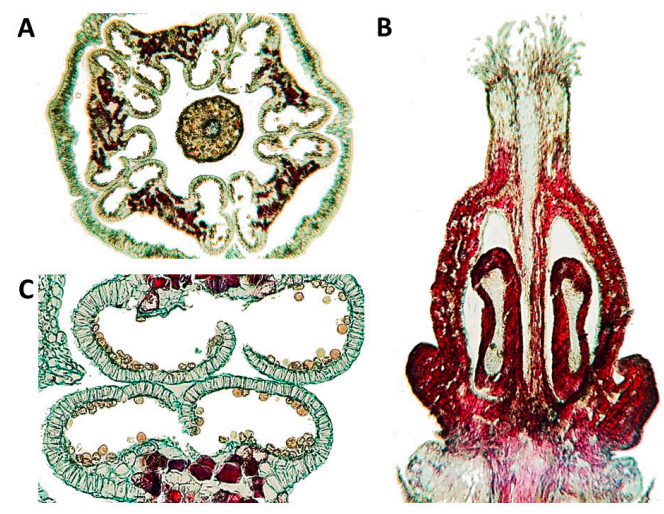

Figure 3. Microscopic images of the unknown cultivar flower tissue on November 16 (E-L 26; cap-fall complete): cross section (A), longitudinal section (B), and anther section (C).

The main conclusions are as follows. An unknown cultivar that was found mixed in a 'Carmenère' vineyard from Chile was successfully identified as cv. 'Folle Blanch Faux' by its SSR allelic pattern. This cultivar was characterized by classic ampelography using the OIV codes, and its phenology was described. The flowers are morphologically complete, but its inflorescences/ bunches showed a severe physiological disorder 
at the moment of fruit set that begins with stigma necrosis and then proceeds into complete bunch necrosis. Cane girdling at bloom time completely overcame the necrosis and induced berry set, growth and the final ripening. This cultivar could become an interesting tool for physiological and molecular studies.

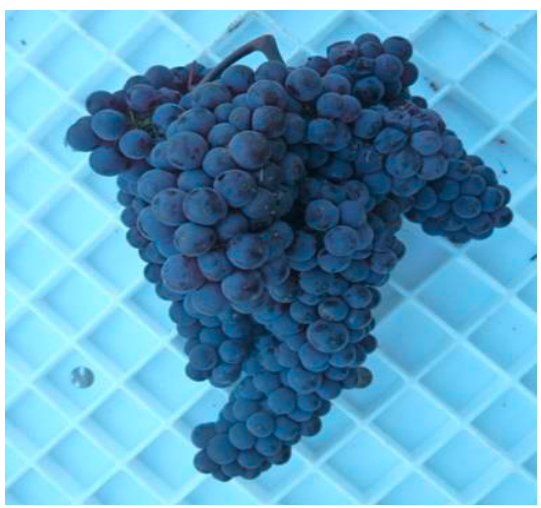

Figure 4. Unknown cultivar ripe grape cluster at harvest, after cane girdling treatment.
Table 4. Chemical analyses of rosé and red wines made from grapes of the unknown cultivar.

\begin{tabular}{lll}
\hline Parameter & $\begin{array}{l}\text { Rosé } \\
\text { winemaking }\end{array}$ & $\begin{array}{l}\text { Red } \\
\text { winemaking }\end{array}$ \\
\hline Alcohol $(\% \mathrm{v} / \mathrm{v})$ & 14.6 & 14.2 \\
Total acidity $\left(\mathrm{g} \mathrm{H}_{2} \mathrm{SO}_{4} \mathrm{~L}^{-1}\right)$ & 8.66 & 8.03 \\
$\mathrm{pH}$ & 2.96 & 2.95 \\
Total anthocyanins $\left(\mathrm{mg} \mathrm{L}^{-1}\right)$ & 31.1 & 231.5 \\
Total polyphenols $(\mathrm{DO} 280)$ & 0.95 & 36.26 \\
Wine color index & 0.03 & 5.23 \\
Hue & 1.73 & 0.59 \\
\hline
\end{tabular}

\section{Acknowledgments}

We are grateful to "Viña Alta Alcurnia" for kindly providing access to the plant material used in this study. We kindly acknowledge the technical assistance of María Herminia Castro, from INIA, Chile.

\section{Resumen}

A.S. Gonzalez, F. Massera, D. Moscoso, P. Hinrichsen, G. Montenegro, V. Laucou, T. Lacombe, J-M. Boursiquot y Ph. Pszczólkowski. 2016. Identificación y caracterización de un cultivar de vid (Vitis vinifera) original, encontrado en Chile. Cien. Inv. Agr. 43(2):337-345. Actualmente, muchos viñedos monovarietales presentan mezclas de otros cultivares en proporciones menores. Algunos de estos cultivares son desconocidos y podrían representar una oportunidad para descubrir genotipos nuevos y potencialmente útiles en investigación y/o producción. En un viñedo cv. 'Carmenère', plantado en 1994 en la comuna de Palmilla (Valle de Colchagua, Chile), se determinó la presencia minoritaria de otros cultivares. El presente trabajo cubre por primera vez la identificación y caracterización de uno de estos cultivares, el cual presentó una muy pobre fructificación. A través de ampelografía clásica, no fue posible asociar el cultivar en estudio a ningún cultivar conocido en Chile. Sin embargo, a través de una comparación de marcadores moleculares microsatélites con la base de datos del Repositorio de Germoplasma de Vid del INRA "Domaine de Vassal" en Francia, fue identificado como un acceso triploide llamado 'Folle Blanche Faux' (Vitis vinifera L.), el cual había sido descubierto en Chile previamente durante la temporada 1950-1951. Este cultivar presenta una brotación más precoz que la del cv. 'Carmenère', posee flores morfológicamente completas y muestra un notorio desorden fisiológico en su fructificación, el cual se manifiesta a través de una necrosis de racimo parcial o completa, bajo las condiciones ambientales de Palmilla. Este cultivar contribuye a la riqueza genotípica presente en Chile y eventualmente podría llegar a ser una herramienta interesante para estudios fisiológicos y moleculares. Adicionalmente, podría volverse productiva bajo otras condiciones ambientales (i.e. condiciones ambientales que favorezcan una buena cuaja frutal) o por la aplicación de prácticas vitícolas adecuadas, como el anillamiento de cargadores durante la floración.

Palabras clave: Ampelografía, Chile, corrimiento, cuaja, marcadores moleculares, SSR, triploide. 


\section{References}

Alleweldt G, and E. Dettweiler. 1994. The genetic resources of Vitis: world list of grapevine collections, 2nd edn. BAZ IRZ Geilweilerhof, Siebeldingen. Germany. 590 pp.

Boidron R., J.M. Boursiquot, J.P. Doazan, P. Leclair, M. Leguay, and B. Walter. 1995. Catalogue des variétés et clones de vigne cultivés en France. Le Grau du Roi, IFV (Institut Français de la Vigne et du Vin). Montepllier, France. 357 pp.

Bowers, J.E., G.S. Dangl, R. Vignani, and C.P. Meredith. 1996. Isolation and characterization of new polymorphic simple sequence repeat loci in grape (Vitis vinifera L.). Genome 39: 628-633.

Calderón-Baltierra X., G. Montenegro, and E. De García. 2004. Ontogeny of in vitro rooting processes in Eucalyptus globulus. In Vitro Cellular and Developmental Biology - Plant 40: 499. 503.

Di Castri, F., and H. Hajek. 1976. Bioclimatología de Chile. Vicerrectoría Académica Universidad Católica de Chile. Santiago, Chile. 163 pp.

Díaz G.A., J. Auger, X. Besoain, E. Bordeu, and B.A. Latorre. 2013. Prevalence and pathogenicity of fungi associated with grapevine trunk diseases in Chilean vineyards. Cien. Inv. Agr. 40: 327-339.

Einset, J., and C. Pratt. 1954. 'Giant' sports of grapes. Proc. Am. Soc. Hortic. Sci. 63: 251-256.

Gil, G.F., and P. Pszczólkowski. 2015. Viticultura. Fundamentos para optimizar producción y calidad. Second Edition, Ediciones Universidad Católica de Chile. Santiago, Chile. 670 pp.

Hernández, A., and Ph. Pszczólkowski. 1986. La vigne et le vin au Chili. XIX Congres International de la Vigne et du Vin. Facultad de Agronomía e Ingeniería Forestal, Pontificia Universidad Católica de Chile. Santiago, Chile. 253 pp.

Iland, P., N. Bruer, G. Edwards, S. Weeks, and E. Wilkes. 2004. Chemical Analysis of Grapes and Wine Techniques and Concepts, $2^{\text {nd }}$ ed. Patrick Iland Wine Promotions Pty Ltd. Adelaide, Australia. $120 \mathrm{pp}$.

Jackson, D.I. 1991. Environmental and hormonal effects on development of early bunch stem necrosis. Am. J. Enol. Vitic. 42: 290-294.
Mejía, N., M. Gebauer, L. Muñoz, N. Hewstone, C. Muñoz, and P. Hinrichsen. 2007. Identification of QTLs for seedlessness, berry size and ripening date in a seedless $x$ seedless table grape progeny. Am. J. Enol. Vitic. 58: 499-507.

Milla-Tapia, A., J.A. Cabezas, F. Cabello, T. Lacombe, J.M. Martinez-Zapater, P. Hinrichsen, and M.T. Cervera 2007. Determining the Spanish origin of representative ancient American grapevine varieties. Am. J. Enol. Vitic. 58: 242-251.

Narváez, C., M.H. Castro, J. Valenzuela, and P. Hinrichsen. 2001. Patrones genéticos de los cultivares de vides de vinificación más comúnmente usados en Chile basados en marcadores de microsatélites. Agric. Técn. (Chile) 61: 249261.

OIV- Organisation Internationale de la Vigne et du Vin. 2006. Liste des descripteurs OIV pour les varietés et especes de Vitis. 2me edition. Paris, France. 179 pp.

Park, S.M., A. Wakana, J.H. Kim, and C.S. Jeong. 2002. Male and female fertility in triploid grapes (Vitis complex) with special reference to the production of aneuploid plants. Vitis 41: 11-19.

Pelsy, F. 2010. Molecular and cellular mechanisms of diversity within grapevine varieties. Heredity 104: 331-340.

SAG - Servicio Agrícola y Ganadero, Chile. 2015. Catastro nacional de vides de vinificación 2014. Available online at: http:/www.sag.cl/content/ catastro-viticola-nacional-2014 (Website accessed: June 10, 2016).

Sefc, K.M., M.S. Lopes, F. Lefort, R. Botta, K.A. Roubelakis- Angelakis, J. Ibáñez, I. Pejic, H.W. Wagner, J. Glössl, and H. Steinkellner. 2000. Microsatellite variability in grapevine cultivars from different European regions and evaluation of assignment testing to assess the geographic origin of cultivars. Theor. Appl. Genet. 100:498505.

Staudt, G. 1995. Some remarks on triploid grapevines. Vitis 34:129-130.

Thomas, M.R., and N.S. Scott. 1993. Microsatellite repeats in grapevine reveal DNA polymorphisms when analyzed as sequence-tagged sites (STSs). Theor. Appl. Genet. 86: 985-990. 
